\title{
Antiurolithiatic Activity of Ethanolic Extract of Piper cubeba Dried Fruits: An In-vitro and In-vivo Study
}

\section{S. Suman ${ }^{1, *}$, S.V. Suresh Kumar ${ }^{2}$}

\section{S. Suman ${ }^{1, *}$, S.V. Suresh Kumar ${ }^{2}$}

${ }^{1}$ Research Scholar, Jawaharlal Nehru technological University Anantapur, Ananthapuramu-515002, Andhra Pradesh, INDIA.

${ }^{2}$ Department of Pharmacognosy, Creative Educational Society's college of Pharmacy, $\mathrm{NH}-7$, Chinnatekur, Kurnool-518218, Andhra Pradesh, INDIA

\section{Correspondence}

\section{S. Suman}

Research Scholar, Jawaharlal Nehru technological University Anantapur, Ananthapuramu-515002, Andhra Pradesh, INDIA.

E-mail: kalyan.suman1985@gmail.com History

- Submission Date: 03-07-2020;

- Review completed: 09-08-2020;

- Accepted Date: 18-08-2020

DOI : 10.5530/pj.2020.12.177

Article Available online

http://www.phcogj.com/v12/i6

\section{Copyright}

(C) 2020 Phcogj.Com. This is an open access article distributed under the terms of the Creative Commons Attribution 4.0 International license.

\begin{abstract}
Introduction: Piper cubeba is a well-known traditional plant used in unani medicine belonging to the Piperaceae family and has been examined for the treatment of urolithiasis produced by calcium oxalate. Methods: Ethanolic extract of Piper cubeba (EEPC) dried fruits was subjected to phytochemical analysis and HPTLC fingerprinting. An in vitro antiurolithiatic analysis took place through conductometric titrations of $\mathrm{CaCl}_{2}$ with $\mathrm{Na}_{2} \mathrm{C}_{2} \mathrm{O}_{4}$. Acute toxicity studies conducted as per OECD guidelines. Urolithiasis was established in rats by supplementing 28 days with $0.75 \%$ ethylene glycol in the ingesting water. Beside ethylene glycol, EEPC (100, 200 and $400 \mathrm{mg} / \mathrm{kg}$ ) was given orally from 15 - 28 days, serum and urine were collected from individual animals and biochemical parameters like BUN, creatinine along with uric acid in serum as well as calcium, oxalate and phosphate in urine the kidney homogenate have been measured on $28^{\text {th }}$ day. Kidney sections have been organized and histopathologically tested for calcium oxalate crystals. Results: Phytochemical analysis of EEPC disclose the presence of phenolics, tannins, steroids, terpenoids and flavonoids and HPTLC fingerprinting shows the presence of 7 terpenoids, 2 flavonoids when scanned at $540 \mathrm{~nm}$ and $366 \mathrm{~nm}$. In vitro studies showed reduction in $\mathrm{CaOx}$ crystal aggregation and promoted nucleation after treatment with EEPC. In vivo studies also showed reduction in elevated levels of serum creatinine, BUN, uric acid, and levels of calcium, oxalate and phosphate in urine and kidney homogenate as compared to disease control rats. The results were supported by histopathological studies. Conclusion: The EEPC have shown significant antiurolithiatic activity by reducing calculi. Key words: Calcium oxalate, Ethylene glycol, Flavonoids, HPTLC, Terpenoids, Urolithiasis.
\end{abstract}

\section{INTRODUCTION}

Urolithiasis is frequently combatted in its various forms during urological hurdles and is a major health issue. Some common causes include insufficient urinary drainage, external bodies in urinary area, bacterial contagions, and excessive oxalate along with calcium diets, gout and intestinal dysfunction ${ }^{1}$. It comprises as a worldwide health issue with an incidence of up to $5 \%$ in the overall public, but its prevalence is greater in certain geographic areas like $70 \%$ in Gulf nations, $15 \%$ in the US and Turkey, $11 \%$ in India as well as 4-8 $\%$ in United Kingdom ${ }^{2,3}$.This condition is almost twofold as mutual in males as in females along with its occurrence is rises as per age in adults ${ }^{4}$.

Pipercubeba L., or tailed pepper belongs to the family of Piperaceae. This particular plant is actually a folk herb and has long been utilized as a spice in most places, such as Indonesia, India, Morocco as well as Europe (Middle Ages).In classical Unani literature, Piper cubeba (Kabab chini) is extensively described and various plant actions includes Mudirr-e- baul (Diuretic), Mukhrij-e- sang-e- gurdah wa masanah (Lithotriptic), Munaqq-e- kulyah wa masanah (Cathartic for kidney and bladder), Mulattif (Demulcent), Habis-e- ishal (Astringent), Dafa-etaaffun (Anti septic), Mufattih-e- sudad-e- jigar (Deobstructive), Muqavvi-e- jigar (Hepatotonic) Muhallil (Anti-inflammatory), Mutayyib-e-dahan (Mouth Refreshner), Muharrik (Stimulant),
Nafey-e Zeeq un nafas (Anti-asthmatic), Kasire-riyah (Carminative), Musakkin (Sedative), Muqawwi-e meadah (Gastrotonic) ${ }^{5,6,7}$

Though, no analyses have been documented consequently as on antiurolithiatic activity of Piper cubeba. Hence, the given study was made an attempt to found the scientific data for the antiurolithiatic activity of EEPC beside ethylene glycol produced urolithiasis in rats.

\section{MATERIALS AND METHODS}

\section{Collection of plant material}

Dried fruits of plant material purchased as of Sirigiri Venkappa ayurvedic stores, Kurnool, Andhra Pradesh, India in July 2017, authenticated and conformed by Raw material herbarium and museum, NISCAIR, Delhi, India by a reference no.(NISCAIR/ RHMD/ Consult/ 2017/3091-40). The dried fruits have been pulverized to get the coarse powder used for extraction.

\section{Preparation of extract}

The coarse powder of Piper cubeba fruits crammed in a thimble and was subjected to extraction by using Sohxlet apparatus, with ethanol. The extract was filtered, and the residue obtained at laboratory temperature after concentration in the bath of water was additionally evaporated as well as stored in desiccator till utilization.

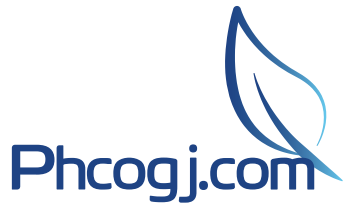

Cite this article: Suman S, Kumar SVS. Antiurolithiatic Activity of Ethanolic Extract of Piper cubeba Dried Fruits: An In-vitro and In-vivo Study. Pharmacogn J. 2020;12(6):1289-96. 


\section{Phytochemical screening}

The ethanolic extract of Piper cubeba dried fruits (EEPC) sample was exposed to initial phytochemical screening for alkaloids, glycosides, tannins, phenols, steroids, flavonoids as well as terpenoids following standard procedures 8 .

\section{HPTLC analysis of ethanolic extract of Piper cubeba dried fruits}

The ethanolic extract of Piper cubeba dried fruits (EEPC) was applied at a concentration of $2 \mu \mathrm{l}$ using the CAMAG Automatic TLC sampler 4 applicator over pre-coated silica gel 60 F254 TLC plates (Merck) $0.2 \mathrm{~mm}$ thick, $5 \mathrm{~cm} \times 20 \mathrm{~cm}$, as a stationary phase. Plates have been industrialized through using ethyl acetate: formic acid: acetic acid: water (100:11:11:26) v / v / v/ v, n-hexane: ethyl acetate $(1: 1) \mathrm{v} / \mathrm{v}$, by the mobile phase means for flavonoids ${ }^{9}$ and terpenoids respectively. The plates were industrialized in CAMAG - glass chamber which was twin trough saturated with saturated pad for 20 minutes, to a distance of $70 \mathrm{~mm}$. Developed plates have been derivatized with Anisaldehyde sulphuric acid and Natural product reagent respectively for terpenoids and flavonoids using CAMAG derivatizer. The tracks are scanned densitometrically using Camag scanner at a wave length of $540 \mathrm{~nm}$ for terpenoids and $366 \mathrm{~mm}$ for flavonoids, and the finger print profiles are recorded for terpenoids and flavonoids. The data was analysed using Camag software, Vision CATS.

\section{Evaluation of in-vitro antiurolithiatic activity}

The Piper cubeba ethanolic extract on $\mathrm{CaOx}$ crystallization was governed through the extent of variations in turbidity owing to crystal nucleation along with aggregation. The turbidity of Calcium oxalate was recorded at $620 \mathrm{~nm}$ at $37^{\circ} \mathrm{C}$ and $\mathrm{pH}$ 6.8. The UV / Vis (Lab India) spectrophotometer was utilized to turbidity determination of the rise in calcium oxalate.

\section{Nucleation assay}

The effect of the ethanolic extract of Piper cubeba over the growth of calcium oxalate $(\mathrm{CaOx})$ crystal was through nucleation assesses. Individually, calcium chloride $(3 \mathrm{mM})$ as well as sodium oxalate $(0.5 \mathrm{mM})$ explanations were filtered three times through the pore size of $0.22 \mu \mathrm{m}$ filter, from that $950 \mu \mathrm{L}$ of calcium chloride was took and to this added $100 \mu \mathrm{L}$ of extract at different concentrations $(50 \mu \mathrm{g}-3200 \mu \mathrm{g} / \mathrm{mL})$. Then added $950 \mu \mathrm{L}$ of sodium oxalate solution for initiation of crystals. Then finally the solutions were attractively moved at $800 \mathrm{rpm}$ with an inspiring bar. The temperature $37^{\circ} \mathrm{C}$ was preserved. At $620 \mathrm{~nm}$ the solution optical density has been monitored. The nucleation rate was determined through associating the induction time (the delay ahead of the crystals exterior that have extended a critical size then consequently turn out to be optically demonstrable) if the control with the extract occurrence of no need to addition of corm extracts ${ }^{10}$.

\section{Aggregation assay}

The ethanolic extract of Piper cubeba influence on calcium oxalate $(\mathrm{CaOx})$ crystal aggregation was resolved through aggregation assay. $0.8 \mathrm{mg} / \mathrm{mL}$ COM crystals were buffered with $0.05 \mathrm{M}$ Tris containing sodium chloride $(0.15 \mathrm{M})$ at $\mathrm{pH} 6.5$. Those all were performed at the temperature $37^{\circ} \mathrm{C}$ in the presence and corm extract absence afterward the stirring apprehends. The aggregation rate was predictable as below mentioned formula, through associating the turbidity slope in the sample and through that turbidity in the controller ${ }^{11}$.

$$
\text { Ir }=\frac{\text { Turbidity of Sample }}{\text { Turbidity of control }}
$$

Ir $=$ Percentage aggregation inhibition rate

\section{Evaluation of in-vivo pharmacological studies:}

\section{Selection of animals}

Healthy wistar albino rats whose weight was approximately 150-180 g are collected from animal house, CES college of pharmacy, Kurnool. In polypropylene cages the animals were kept, preserved at $27 \pm 2{ }^{\circ} \mathrm{C}$ with in a qualified humidity of $65 \pm 10 \%$, through $12 \mathrm{~h}$ of light and dark cycles. Animals were fed with regular pellet diet manufactured through Nutrivet life sciences, Pune, India and protocol have been accepted through the IAEC with protocol No.: IAEC/CESCOP/2017-10.

\section{Acute toxicity studies}

In accordance to OECD 423 regulations, for acute toxicity studies male albino mice ( $20 \mathrm{~g}$ body weight) have been used ${ }^{12}$. For oral administration of EEPC to the overnight fasted animals, EEPC has been suspended in $1 \%$ sodium CMC. To distinguish behavioural alterations, the animals were continuously monitored for $3 \mathrm{~h}$ along with each $30 \mathrm{~min}$ aimed at next $3 \mathrm{~h}$ as well as then up to $24 \mathrm{~h}$. Animals were also experiential aimed at the next 14 days to identify humanity as well as social variations. For the effective dosage non-median lethal dose's $\left(\mathrm{LD}_{50}\right) 1 / 10^{\text {th }}$ part is used $^{13}$.

\section{Antiurolithiatic activity}

\section{Ethylene glycol induced urolithiasis in wistar albino rats}

Atmani $e a^{14}$. described a method that was used for the antiurolithiatic activity evaluation of ethanolic extract of Piper cubeba in albino rats. Thirty-six rats were allocated in six groups, every group involving of six rats.

\section{Group-1 normal control}

Group-2 Disease control cured with ethylene glycol (0.75\%) for 28 days

Group-3 Standard treated with ethylene glycol (0.75\%) for 28 days and Cystone $(750 \mathrm{mg} / \mathrm{kg})$ from $15^{\text {th }}$ day- $28^{\text {th }}$ day

Group-4-6 test groups established ethylene glycol (0.75\%) for 28 days along with ethanolic extract of Piper cubeba dried fruits at the doses of $(100 \mathrm{mg} / \mathrm{kg}, 200 \mathrm{mg} / \mathrm{kg}$ and $400 \mathrm{mg} / \mathrm{kg})$ correspondingly as of $15^{\text {th }}$ day$28^{\text {th }}$ day.

\section{Assessment of antiurolithiatic activity}

\section{Serum analysis:}

After last dose of the EEPC treatment, blood was composed through retro-orbital plexus below slight anaesthetic conditions. By centrifugation Serum was unglued (Research Centrifuge, R-22, Remi India) at $10,000 \times \mathrm{g}$ for $10 \mathrm{mins}$ as well as examined aimed at creatinine, uric acid as well as blood urea nitrogen (BUN) through semi-auto analyser (Mispa Excel Chemistry analyser) with diagnostic kits of Excel Diagnostic Pvt. Ltd, Hyderabad.

\section{Urine analysis}

On the $28^{\text {th }}$ day individual animal was kept in separate metabolic cages; $24 \mathrm{hr}$ of urine sample was collected. Provide the water for rats all through the collection of urine, urine sample was subjected aimed at estimation of Calcium (Calcium diagnostic Kit, Agappe Diagnostics Ltd, Kerala, India), Oxalate ${ }^{15}$ and Phosphate ${ }^{16}$.

\section{Kidney homogenate analysis and histopathology}

At the study period end, the rats were euthanized using a $\mathrm{CO}_{2}$ chamber along with the abdomen was cut open to eliminate mutual kidneys as of every rat. The extracted kidneys remained washed off irrelevant tissue as well as rinsed in saline which is ice-cold physiological, utilized 
for histopathology as well as homogenate study. The left kidney of the individual rats was excellently chopped along with $20 \%$ of homogenate was organised in the Tris-Hcl buffer $(0.02 \mathrm{~mol} / 1, \mathrm{pH} 7.4)$ and tested for Calcium, oxalate as well as phosphate. The right kidney have been immovable in formalin of $10 \%$ neutral buffered, and dealed with a sequence of graded alcohol as well as xylene and fixed in paraffin wax, partitioned at $5 \mu \mathrm{m}$ as well as marked with Hematoxylin and Eosin aimed at inspection beneath polarized light, With the help of Olympus Digital Camera, histopathological examination of slides was carried out under polarized light microscope (40X) and photographs were taken.

\section{Statistical analysis}

Every value is articulated as mean \pm SEM. The data was statistically studied through utilizing one-way ANOVA surveyed through Dunnett's t assessment in GraphPad Prism 5.03 version software.

\section{RESULTS}

Preliminary phytochemical screening of ethanolic extract Piper cubeba dried fruits

The screening of Phytochemical discloses the phenolics presence, tannins, steroids, terpenoids and flavonoids in ethanolic extract of Piper cubeba dried fruits.

\section{HPTLC analysis of ethanolic extract of Piper cubeba dried fruits}

To obtain the reproducible results with high resolution different combinations of solvents with various ratios were tested. Satisfactory results were obtained with n-hexane: ethyl acetate $(1: 1) \mathrm{v} / \mathrm{v}$ as well as ethyl acetate: water: formic acid: acetic acid (100:26:11:11) v/v/v/v for terpenoids and flavonoids respectively. The ethanolic extract of Piper cubeba dried fruits showed the presence of 7 terpenoids, 2 flavonoids with different $\mathrm{Rf}$ values and \% of area when scanned at 540nm (Figure 1 ) and $366 \mathrm{~nm}$ (Figure 2) respectively for terpenoids and flavonoids after derivatization (Table 1).

\section{In-vitro antiurolithiatic activity}

In the present study the different graded concentrations i.e. from $50 \mu \mathrm{g} /$ $\mathrm{ml}$ to $3200 \mu \mathrm{g} / \mathrm{ml}$ of ethanolic extract of Piper cubeba dried fruits were utilized aimed at invitro antiurolithiatic activity evaluation. The reticence of crystal formation was directly proportional to the increase in the concentration of EEPC, with maximum activity was pragmatic at $3200 \mu \mathrm{g} / \mathrm{ml}$ in $\mathrm{CaOx}$ crystal nucleation and aggregation assays (Graphs 1 and 2).
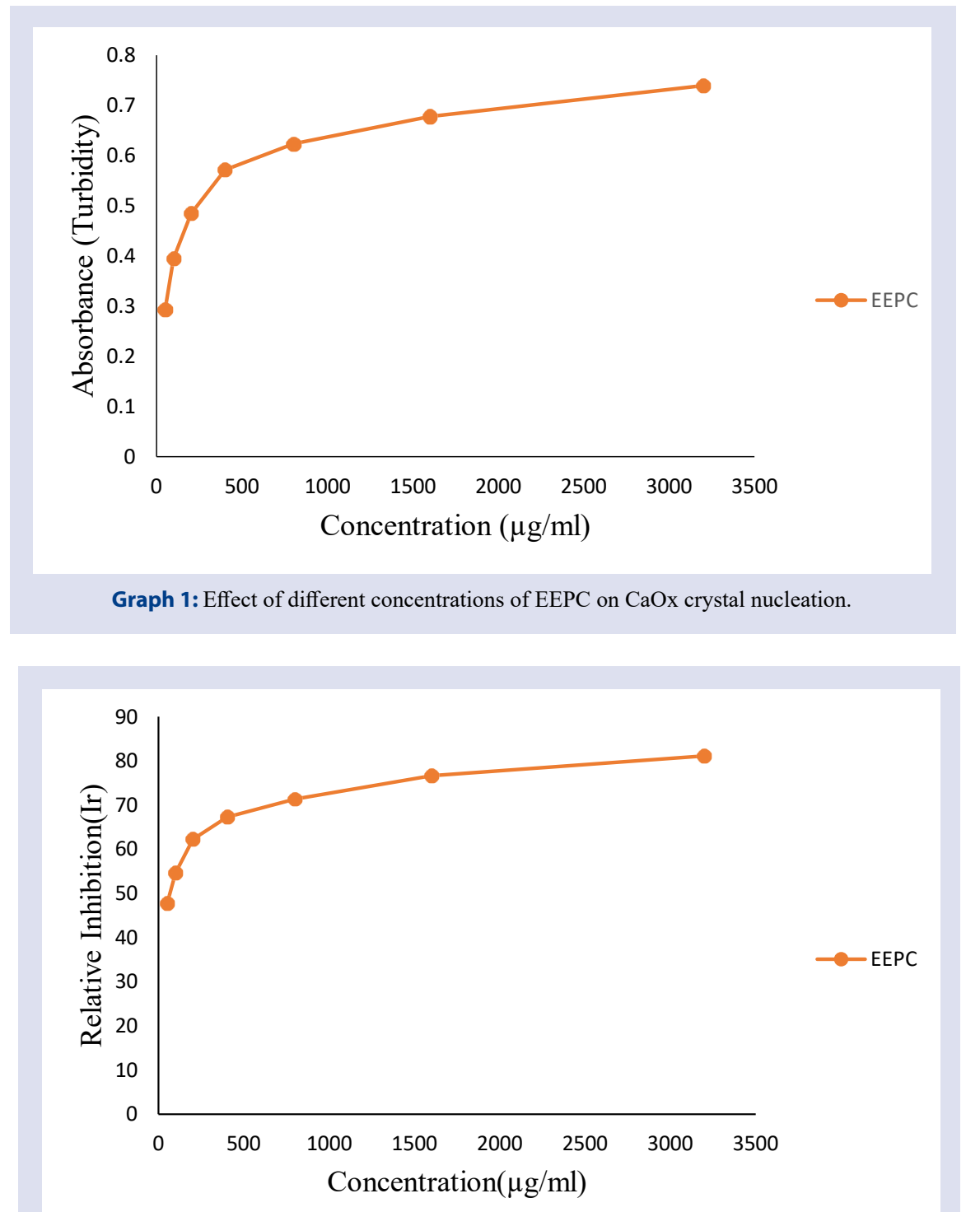

Graph 2: Effect of different concentrations of EEPC on CaOx crystal aggregation. 


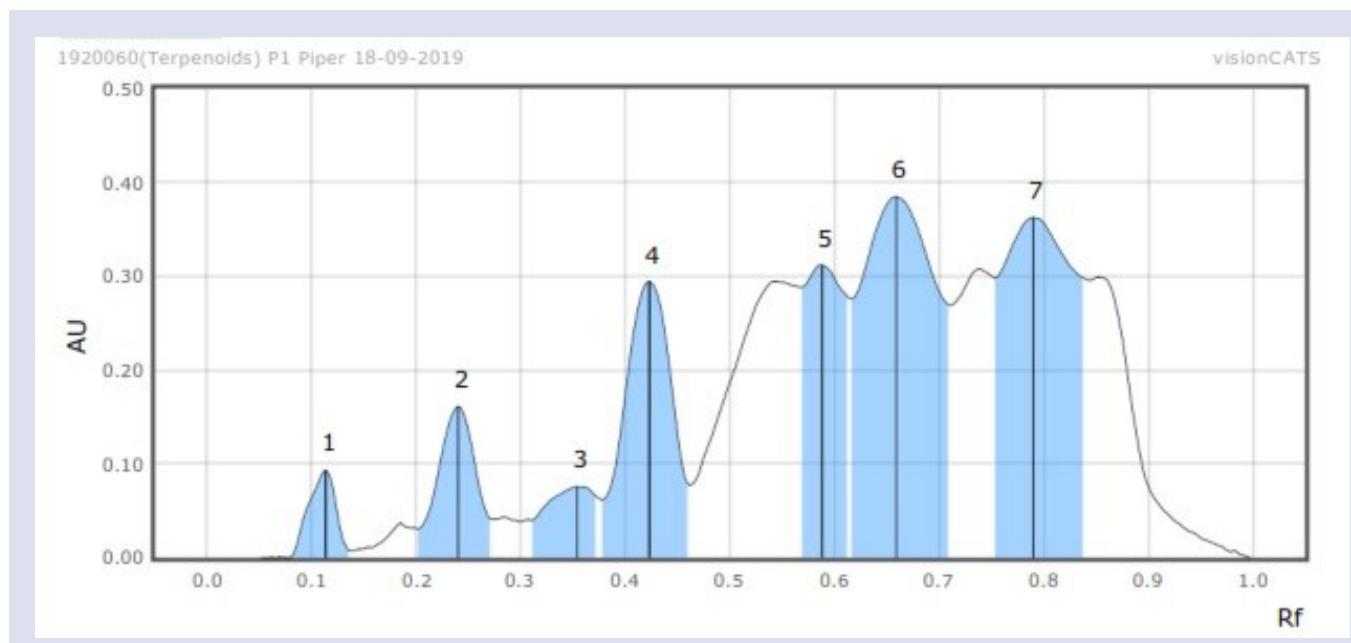

Figure 1: HPTLC chromatogram of terpenoids in $2 \mu \mathrm{l}$ of EEPC.

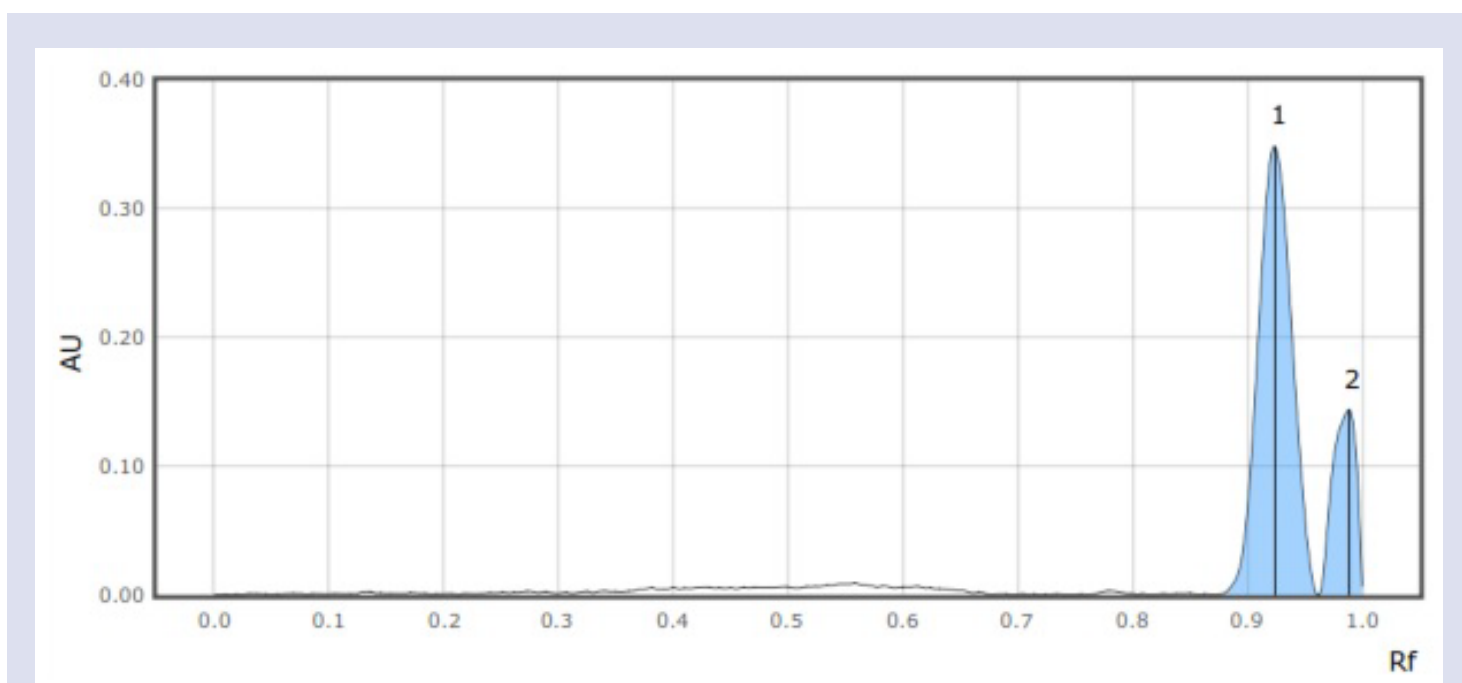

Figure 2: HPTLC chromatogram of flavonoids in $2 \mu$ l of EEPC.

Table 1: HPTLC analysis of EEPC.

\begin{tabular}{ccccc}
\hline \multirow{2}{*}{ Compound } & \multicolumn{2}{c}{ Terpenoids } & \multicolumn{2}{c}{ Flavonoids } \\
\cline { 2 - 5 } & Rf & \% Area & Rf & \% Area \\
\hline 1 & 0.065 & 1.92 & 0.840 & 63.59 \\
2 & 0.198 & 3.80 & 0.958 & \\
3 & 0.319 & 2.42 & & \\
4 & 0.381 & 10.69 & & \\
5 & 0.469 & 17.77 & & \\
6 & 0.589 & 29.90 & & \\
7 & 0.713 & 33.51 & & \\
\hline
\end{tabular}

\section{Evaluation of in-vivo pharmacological studies}

\section{Acute toxicity studies}

The limit test was completed with a measure of EEPC $(2000 \mathrm{mg} / \mathrm{kg}$, b.w) given by oral path to a group of mice utilizing an oral feed needle (22 gauge). Upon treatment, mice were examined for 14 days and no changes in normal behavior were detected, as a result of which it was concluded that the EEPC was experimentally non-toxic in standard mice along with that the non-medium lethal dose of $1 / 20^{\text {th }}(100 \mathrm{mg}$ / kg b.w), 1/10th of the dose ( $200 \mathrm{mg} / \mathrm{kg}$ b.w), 1/5th of the dose (400 $\mathrm{mg} / \mathrm{kg}$ b.w) was considered as smaller, medium and high doses for further pharmacological studies.
Ethylene glycol induced urolithiasis in wistar albino rats

\section{Serum analysis}

The current study treatment with ethylene glycol $(0.75 \%$, p.o $)$ results in a substantial $\left({ }^{\# \# \#} \mathrm{p}<0.001\right)$ elevation in higher level of $(43.36 \pm 1.04,6.93$ $\pm 0.24,6.741 \pm 0.52)$ serum BUN, creatinine and uric acid respectively when comparison is made with normal group. These changes were restored significantly in the rats treated with standard drug cystone $(750 \mathrm{mg} / \mathrm{kg}, \mathrm{p} . \mathrm{o})$ treated group animals acceptably lowers the BUN levels, creatinine along with uric acid respectively ( ${ }^{* * *} \mathrm{p}<0.001 ; 26.02 \pm$ $3.44,2.77 \pm 0.34,3.98 \pm 0.27)$. However, rats treated with EEPC $(100 \mathrm{mg} /$ $\mathrm{kg}, \mathrm{p} . \mathrm{o})$ pointedly decreased in $\mathrm{BUN}\left({ }^{* *} \mathrm{p}<0.01 ; 28.54 \pm 2.62\right)$, uric acid 
$\left({ }^{* *} \mathrm{p}<0.01 ; 4.60 \pm 0.34\right)$ and creatinine $\left({ }^{* * *} \mathrm{p}<0.001 ; 3.30 \pm 0.47\right)$, on the EEPC $(200 \mathrm{mg} / \mathrm{kg}, \mathrm{p} . \mathrm{o})$ substantially $\left({ }^{* * *} \mathrm{p}<0.001\right)$ dose lowered the BUN as well as creatinine $(27.42 \pm 2.17,3.06 \pm 0.47)$ and uric acid $\left({ }^{* *} \mathrm{p}<0.01\right.$; $4.47 \pm 0.48)$, at the EEPC $(400 \mathrm{mg} / \mathrm{kg}, \mathrm{p} .0)$ dose substantially lowered the $\left({ }^{* * *} \mathrm{p}<0.001 ; 26.85 \pm 2.40,2.57 \pm 0.51,3.96 \pm 0.44\right) \mathrm{BUN}$, creatinine as well as uric acid respectively in comparison to the group of disease control (Table 2).

\section{Urine analysis}

In wistar albino rats hyperoxaluria was generated through administration of Ethylene glycol $(0.75 \%)$. In the calculus-induced animals, the urinary calcium levels as well as oxalate $(\# \#$ p $<0.001$; $6.97 \pm 0.47,6.42 \pm 0.49)$ and phosphate $\left({ }^{\# \#} \mathrm{p}<0.01 ; 6.05 \pm 0.73\right)$ were improbably increased. Standard drug cystone $(750 \mathrm{mg} / \mathrm{kg}$, p.o) treated group animals acceptably dropped the calcium levels of $\left({ }^{* * *} \mathrm{p}<0.001\right.$; $4.26 \pm 0.45)$, oxalate and phosphate $\left({ }^{\star *} \mathrm{p}<0.01 ; 3.93 \pm 0.65,3.87 \pm 0.58\right)$ respectively. However, treatment with EEPC $(100 \mathrm{mg} / \mathrm{kg}$, p.o) non meaningfully dropped the elevated calcium level (ns $\mathrm{p}>0.05 ; 5.35 \pm$ 0.28 ) and knowingly dropped the elevated oxalate levels) along with phosphate $\left({ }^{*} \mathrm{p}<0.05 ; 4.53 \pm 0.39,3.99 \pm 0.40\right)$, at the dose of EEPC (200mg/kg, p.o) abridged the elevated calcium and phosphate levels $\left({ }^{* *} \mathrm{p}<0.01 ; 4.84 \pm 0.52,3.63 \pm 0.28\right)$, oxalate $\left({ }^{*} \mathrm{p}<0.05 ; 4.23 \pm 0.44\right)$, at the dose of $E E P C(400 \mathrm{mg} / \mathrm{kg}$, p.o) reduced calcium, oxalate and phosphate levels $\left({ }^{* *} \mathrm{p}<0.01 ; 4.61 \pm 0.52,3.73 \pm 0.50,3.55 \pm 0.25\right)$ in urine when associated to the disease control group (Table 3 ).

\section{Kidney homogenate analysis}

In the renal tissue, deposition of crystalline components viz. oxalate, calcium as well as phosphate were increased knowingly $(\# \# * 0.001 ; 7.94$ $\pm 0.52,7.90 \pm 0.67,7.93 \pm 0.55)$ in the Ethylene glycol $(0.75 \%)$ administered group. The animals treated with cystone $(750 \mathrm{mg} / \mathrm{kg}, \mathrm{p.o})$ standard drug pointedly dropped the raised calcium and phosphate levels remained $\left({ }^{* *} \mathrm{p}<0.01 ; 4.54 \pm 0.53,4.10 \pm 0.67\right)$, and oxalate $\left({ }^{* * *} \mathrm{p}<0.001 ; 3.10 \pm 0.59\right)$. However, treatment with $E E P C(100 \mathrm{mg} / \mathrm{kg}, \mathrm{p} . \mathrm{o})$ pointedly ( $\left.{ }^{*} \mathrm{P}<0.05 ; 5.16 \pm 0.87,5.18 \pm 0.88\right)$ reduced the concentrations calcium, phosphate and oxalate ( $(* \mathrm{p}<0.01 ; 4.05 \pm 0.54)$ correspondingly, at the EEPC $(200 \mathrm{mg} / \mathrm{kg}$, p.o) dose suggestively dropped the raised of calcium, phosphate $\left({ }^{* *} \mathrm{p}<0.01 ; 4.78 \pm 0.68,4.56 \pm 0.57\right)$ and oxalate $\left({ }^{* * *} \mathrm{p}<0.001 ; 3.45 \pm 0.39\right)$ levels and at the $\operatorname{EEPC}(400 \mathrm{mg} / \mathrm{kg}, \mathrm{p} . \mathrm{o})$ dose significantly decreased the raised levels of calcium (** $\mathrm{p}<0.01 ; 4.46 \pm$ $0.25)$, oxalate and phosphate $\left({ }^{* * *} \mathrm{p}<0.001 ; 3.19 \pm 0.56,4.20 \pm 0.46\right)$ in kidney homogenate analysis when associated to the disease control group (Table 4).

Table 2: Effect of Ethanolic extract of Piper cubeba over serum levels of BUN, Creatinine and uric acid in ethylene glycol (0.75\%) prompted urolithiasis in rats.

\begin{tabular}{cccc}
\hline S.no & Groups & $\begin{array}{c}\text { BUN } \\
(\mathrm{mg} / \mathrm{dl})\end{array}$ & $\begin{array}{c}\text { Creatinine } \\
(\mathrm{mg} / \mathrm{dl})\end{array}$ \\
\hline $\mathbf{1}$ & Normal & $24.81 \pm 1.83$ & $2.38 \pm 0.15$ \\
$\mathbf{2}$ & Disease Control & $43.36 \pm 1.04^{* * *}$ & $6.93 \pm 0.24^{* * *}$ \\
$\mathbf{3}$ & Standard (Cystone $750 \mathrm{mg} / \mathrm{kg}, \mathrm{BW})$ & $26.02 \pm 3.44^{* * *}$ & $2.77 \pm 0.34^{* * *}$ \\
$\mathbf{4}$ & EEPC $(100 \mathrm{mg} / \mathrm{kg}, \mathrm{BW})$ & $28.54 \pm 2.62^{* *}$ & $3.70 \pm 0.40$ \\
$\mathbf{5}$ & EEPC $(200 \mathrm{mg} / \mathrm{kg} \mathrm{BW})$ & $27.42 \pm 2.17^{* * *}$ & $3.98 \pm 0.27^{* * *}$ \\
$\mathbf{6}$ & EEPC $(400 \mathrm{mg} / \mathrm{kg} \mathrm{BW})$ & $26.85 \pm 2.40^{* * *}$ & $3.06 \pm 0.47^{* * *}$ \\
\hline
\end{tabular}

Each value is articulated as mean \pm S.E.M for six rats in every group.

Assessments completed amid $\# \#$ $p<0.001$, \#\# $<0.01$, $" \mathrm{p}<0.05$; Normal Vs Disease control,

${ }_{* * *} p<0.001,{ }^{* *} \mathrm{p}<0.01,{ }^{*} \mathrm{p}<0.05$; Disease control Vs Treatment: One-way ANOVA surveyed through Dunnett's -t test.

Table 3: Effect of Ethanolic extract of Piper cubeba on urinary levels of Calcium, oxalate as well as Phosphate in ethylene glycol (0.75\%) persuaded urolithiasis in rats.

\begin{tabular}{|c|c|c|c|c|}
\hline S. No & Groups & $\begin{array}{l}\text { Calcium } \\
\text { (mg/dl) }\end{array}$ & $\begin{array}{l}\text { Oxalate } \\
\text { (mg/dl) }\end{array}$ & $\begin{array}{c}\text { Phosphate } \\
\text { (mg/dl) }\end{array}$ \\
\hline 1 & Normal & $3.06 \pm 0.34$ & $2.31 \pm 0.30$ & $3.55 \pm 0.25$ \\
\hline 2 & Disease Control & $6.97 \pm 0.47^{* * *}$ & $6.42 \pm 0.49^{* * *}$ & $6.05 \pm 0.73^{* *}$ \\
\hline 3 & Standard (Cystone 750mg/kg, BW) & $4.26 \pm 0.45^{* * *}$ & $3.93 \pm 0.65^{* *}$ & $3.87 \pm 0.58^{* *}$ \\
\hline 4 & EEPC $(100 \mathrm{mg} / \mathrm{kg}, \mathrm{BW})$ & $5.35 \pm 0.28^{\mathrm{ns}}$ & $4.53 \pm 0.39^{*}$ & $3.99 \pm 0.40^{*}$ \\
\hline 5 & EEPC (200 mg/kg BW) & $4.84 \pm 0.52^{* *}$ & $4.23 \pm 0.44^{*}$ & $3.63 \pm 0.28^{* *}$ \\
\hline 6 & EEPC (400 mg/kg BW) & $4.61 \pm 0.52^{* *}$ & $3.73 \pm 0.50^{* *}$ & $3.55 \pm 0.25^{* *}$ \\
\hline
\end{tabular}

Each value is stated as mean \pm S.E.M for six rats in every group.

Assessments completed amid ${ }^{\# \# \#} \mathrm{p}<0.001,{ }^{\# \#} \mathrm{p}<0.01,{ }^{\#} \mathrm{p}<0.05$; Normal Vs Disease resistor,

${ }^{* * *} \mathrm{p}<0.001,{ }^{* *} \mathrm{p}<0.01,{ }^{*} \mathrm{p}<0.05$; Disease control Vs Treatment: One-way ANOVA surveyed through Dunnett's -t test.

Table 4: Result of ethanolic extract of Piper cubeba on kidney homogenate levels of Calcium, oxalate and Phosphate in ethylene glycol (0.75\%) prompted urolithiasis in rats.

\begin{tabular}{|c|c|c|c|c|}
\hline S. No & Groups & $\begin{array}{l}\text { Calcium } \\
\text { (mg/dl) }\end{array}$ & $\begin{array}{l}\text { Oxalate } \\
\text { (mg/dl) }\end{array}$ & $\begin{array}{c}\text { Phosphate } \\
\text { (mg/dl) }\end{array}$ \\
\hline 1 & Normal & $3.89 \pm 0.73$ & $2.24 \pm 0.34$ & $3.61 \pm 0.52$ \\
\hline 2 & Disease Control & $7.94 \pm 0.52^{* * *}$ & $7.90 \pm 0.67^{* * *}$ & $7.93 \pm 0.55^{\star * *}$ \\
\hline 3 & Standard (Cystone $750 \mathrm{mg} / \mathrm{kg}, \mathrm{BW}$ ) & $4.54 \pm 0.53^{\star * *}$ & $3.10 \pm 0.59^{* * *}$ & $4.10 \pm 0.67^{\star \star *}$ \\
\hline 4 & EEPC (100 mg/kg, BW) & $5.16 \pm 0.87^{*}$ & $4.05 \pm 0.54^{* *}$ & $5.18 \pm 0.88^{*}$ \\
\hline 5 & EEPC (200 mg/kg BW) & $4.78 \pm 0.68^{* *}$ & $3.45 \pm 0.39^{* * *}$ & $4.56 \pm 0.57^{* *}$ \\
\hline 6 & EEPC (400 mg/kg BW) & $4.46 \pm 0.25^{\star *}$ & $3.19 \pm 0.56^{* * *}$ & $4.20 \pm 0.45^{\star * *}$ \\
\hline
\end{tabular}

Each value is stated as mean \pm S.E.M for six rats in every group.

Assessments completed amid ${ }^{\# \#} \mathrm{p}<0.001,{ }^{\# \#} \mathrm{p}<0.01,{ }^{\#} \mathrm{p}<0.05$; Normal Vs Disease rheostat,

${ }^{* * *} \mathrm{p}<0.001,{ }^{* *} \mathrm{p}<0.01,{ }^{*} \mathrm{p}<0.05$; Disease control Vs Treatment: One-way ANOVA surveyed through Dunnett's -t test. 


\section{Kidney histopathology}

Histopathological examination was performed on the kidneys of rats treated with ethylene glycol $(0.75 \% \mathrm{v} / \mathrm{v})$, which revealed the existence of the bonds of calcium oxalate within the renal tubules along with renal tubules dilation was observed along with interstitial tenderness (Figure 3). The amount of bonds of calcium oxalate in the renal tubules along with the dilation of renal tubules in Group III (Figure 3C) rats was substantially lower than Group II (Figure 3B). EEPC treatment with varying doses $(100 \mathrm{mg} / \mathrm{kg}, \mathrm{BW}$, p.o, $200 \mathrm{mg} / \mathrm{kg}$, BW, p.o, $400 \mathrm{mg}$ / kg, BW, p.o) i.e. category IV-VI (Figure 3D-3F);Suggestively lowers the deposition of calcium oxalate crystal, dilation of renal tubules as well asinterstitial inflammation compared to Group-II (Figure 3B).

\section{DISCUSSION}

In urolithiasis, $\mathrm{CaOx}$ urolithiasis is the utmost predominant kind of every urinary diseases related to the stone. Important magnitudes concerned in its pathological biomineralization comprise crystal nucleation, accumulation and evolution. Present analysis was aimed to discourse these crucial events concerned in $\mathrm{CaOx}$ stone development as a source to take a look at the effectiveness of P. cubeba as an antiurolithiatic agent. In-vitro conditions, nucleation is an essential in the pathogenesis of $\mathrm{CaOx}$ urolithiasis. Nucleation fundamentally
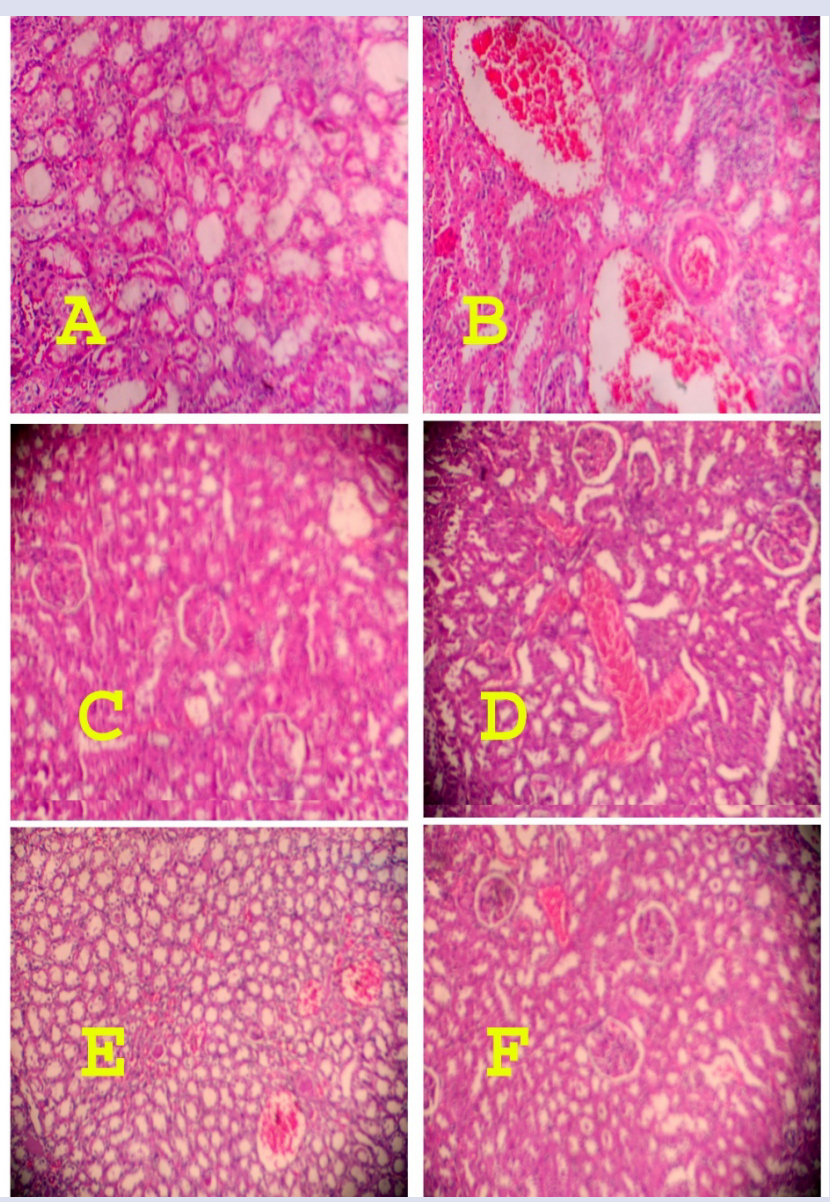

Figure 3: Histopathological view of the experimental groups. Sections show the hematoxylin and eosin (HE) stained kidney. Sections were viewed using polarized light microscope (40X) and photographed by an Olympus Digital Camera.

A-Normal group; B-Disease control (Ethylene glycol $0.75 \% \mathrm{v} / \mathrm{v}$ ); C-Standard (Cystone $750 \mathrm{mg} / \mathrm{kg}$, bd.wt); D-EEPC (100mg/kg, bd. wt); E-EEPC (200mg/kg, bd. wt); F-EEPC (400mg/kg, bd. wt) represents a thermodynamically pushed occasion of phase alteration wherein dissolved substances in a supersaturated solution impulsively crystallize $^{17-19}$ Similar phase change and formation of $\mathrm{CaOx}$ crystals was witnessed while carrying out nucleation assay. The reticence of crystal formation was directly proportional to the increase in the concentration of $E E P C$, with maximum activity was pragmatic at $3200 \mu \mathrm{g} / \mathrm{ml}$ in $\mathrm{CaOx}$ crystal nucleation.

This implies the anticrystallization actions of EEPC from $\mathrm{CaOx}$ crystallization. A particular probable mechanism of anticrystallization actions of EEPC might be the proficiency of it's to be complicated with totally free calcium as well as oxalate ions, therefore obstructing the development of $\mathrm{CaOx}$ complexes, as has also been suggested for Sarghassum wightti ${ }^{19}$.

Aggregation is an important factor of crystal retention as huge crystal agglomerates are actually the people which make renal tubular obstruction therefore encouraging stone formation. EEPC showed considerable inhibitory impact on $\mathrm{CaOx}$ crystal accumulation.

In vivo conditions, oxalate is usually excreted as unaltered in urine. Nevertheless, hyperoxaluria facilitates the development of calcium oxalate renal calculi ${ }^{20}$, because urinary oxalic acid appears to complex with calcium and form insoluble $\mathrm{CaOx}$ crystals in the kidney ${ }^{21}$. Consequently, conditions which promote the absorption of oxalate from the production of food (or) endogenous oxalate may cause the formation of $\mathrm{CaOx}$ stone ${ }^{22}$.

It has been confirmed that ingested ethylene glycol is converted to oxalic acid by the presence of liver enzyme glycolate oxidase ${ }^{23}$, thus facilitating the accumulation of $\mathrm{CaOx}$ in the kidneys.

In the current analysis rats fed by means of ethylene glycol $(0.75 \% \mathrm{v} / \mathrm{v})$ resulted substantial rise in serum stages of BUN, creatinine and uric acid as well as promotes excessive excretion of urinary levels of calcium, oxalate and phosphate, indicates calcium oxalate stones formation in kidneys. However, treatment with EEPC, significantly lowers the raised levels of BUN, creatinine along with uric acid along with urinary levels of calcium, oxalate and phosphate in a dose reliant on style.

Microscopic investigation of the sectional rat kidney treated with ethylene glycol shows the presence of calcium oxalate bonds, dilatation of renal tubules accompanied through interstitial inflammation. However, cotreatment through EEPC reduces the number of calcium oxalate bonds, dilatation of renal tubules as well as prevents the damage to renal tubules in dose dependent manner.

The phytoconstituent found in the citation can be accountable for the movement, aimed at instance flavonoids, tannins, phenolic, steroids and terpenoids. In previous literature, flavonoids ${ }^{24}$ and terpenoids ${ }^{25}$ performs a significant part in the antiurolithiatic activity. Attempt also made to standardise the extract by performing finger printing of flavonoids and terpenoids by HPTLC.

\section{CONCLUSION}

The findings of this assessment provide strong evidence that the EEPC avoids the calcium oxalate crystals development in in vitro. Oral administration of EEPC to ethylene glycol mediated urolithiasis results in a dose-dependent decrease in raised serum levels of BUN, Creatinine as well as uric acid and urinary calcium, oxalate and phosphate. Therefore, EEPC expressed considerable antiurolithiatic activity against urolithiasis caused by ethylene glycol in rats.

\section{ACKNOWLEDGEMENTS}

The authors made their gratitude toward the authorities of the Creative Educational Society's College of Pharmacy, Chinnatekur, Kurnool, Andhra Pradesh, India, intended for offering these facilities. 


\section{CONFLICTS OF INTEREST}

The authors have stated that there is no conflicts of interest.

\section{REFERENCES}

1. Tiselius HG. Etiology and investigation of stone disease. European Urology. 1998;33(3):A1-7.

2. Eggermann T. Genetics of urolithiasis. Euro Med J. 2014;29:1-7.

3. Sudarsanam SR, Moonandi M. Potency of Kara sooda sathu parpam A herbo mineral siddha drug in the management of Kalladaippu noi (Urolithiasis) A drug review. Int J Res Ayurveda Pharm. 2014;5(3):372-9.

4. Dal Moro F, Mancini M, Tavolini IM, De Marco V, Bassi P. Cellular and molecular gateways to urolithiasis: a new insight. Urologia internationalis. 2005;74(3):193-7.

5. Razi Z. Al-Havi Al-kabir. Dairatul Maarif Osmania Hyderabad. 1967;21:391-2.

6. Baitar I. Al-Jam-e-ul-Mufradat-Al-Adviah-Wal-Aghziya (Urdu translation). CCRUM publication, New Delhi. 1999.

7. Zurair AD. Tazkiratu ulil Albab wal jameu lil Ajab al Ujab Matba Al mamaniah Misr. YNM, I.:247-8.

8. Kokate CK, Purohit AP, Gokhale SB. Pharmacognosy. Pune: Nirali prakashan; 2008.

9. Wagner H, Bladt S. Plant drug analysis: a thin layer chromatography atlas. Springer Science \& Business Media. 2007;195-210.

10. Hennequin C, Lalanne V, Daudon M, Lacour B, Drueke T. A new approach to studying inhibitors of calcium oxalate crystal growth. Urological Research. 1993;21(2):101-8.

11. Hess B, Nakagawa YA, Coe FL. Inhibition of calcium oxalate monohydrate crystal aggregation by urine proteins. American Journal of Physiology-Renal Physiology. 1989;257(1):F99-106.

12. OECD 423. OECD Guideline for Testing of Chemicals Acute Oral Toxicity-Acute Toxic Class Method Adopted.

13. Handa SS, Sharma A. Hepatoprotective activity of andrographolide from Andrographis paniculata against carbontetrachloride. The Indian Journal of Medical Research. 1990;92:276.
14. Atmani F, Slimani Y, Mimouni M, Hacht B. Prophylaxis of calcium oxalate stones by Herniaria hirsuta on experimentally induced nephrolithiasis in rats. BJU International. 2003;92(1):137-40.

15. Hodgkinson A, Williams AN. An improved colorimetric procedure for urine oxalate. Clinica Chimica Acta. 1972;36(1):127-32.

16. Fiske $\mathrm{CH}$, Subbarow $\mathrm{Y}$. The colorimetric determination of phosphorus. J Bio Chem. 1925;66(2):375-400.

17. Aggarwal KP, Narula S, Kakkar M, Tandon C. Nephrolithiasis: molecular mechanism of renal stone formation and the critical role played by modulators. BioMed Research International. 2013;2013.

18. Basavaraj DR, Biyani CS, Browning AJ, Cartledge JJ. The role of urinary kidney stone inhibitors and promoters in the pathogenesis of calcium containing renal stones. EAU-EBU Update Series. 2007;5(3):126-36.

19. Sujatha D, Singh K, Vohra M, Kumar KV, Sunitha S. Antilithiatic Activity of phlorotannin rich extract of Sarghassum Wightii on Calcium Oxalate UrolithiaisIn Vitro and In Vivo Evaluation. International Braz J Urol. 2015;41(3):511-20.

20. Robertson WG, Peacock M. The cause of idiopathic calcium stone disease: hypercalciuria or hyperoxaluria? Nephron. 1980;26(3):105-10.

21. Danpure CJ. Primary hyperoxaluria. The metabolic and molecular bases of inherited disease. 1995;11:2385-424.

22. von Unruh GE, Voss S, Sauerbruch T, Hesse A. Dependence of oxalate absorption on the daily calcium intake. Journal of the American Society of Nephrology. 2004;15(6):1567-73.

23. Khan SR, Hackett RL. Calcium oxalate urolithiasis in the rat: is it a mode for human stone disease? A review of recent literature. Scanning Electron Microscopy. 1985:759-74

24. Zeng $X, X i Y$, Jiang $W$. Protective roles of flavonoids and flavonoid-rich plant extracts against urolithiasis: A review. Critical Reviews in Food Science and Nutrition. 2019;59(13):2125-35.

25. Dinnimath BM, Jalalpure SS. In silico antiurolithiatic screening of Aerva lanata (L) isolated constituents. Indian J Pharm Educ Res. 2015;49(1):1-8.

\section{GRAPHICAL ABSTRACT}

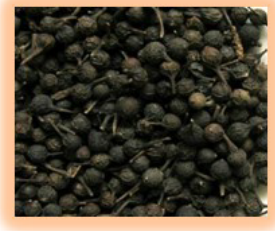

Piper cubeba dried fruits

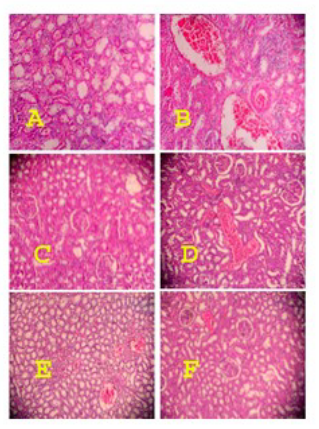

Histopathological sections of rat kidneys

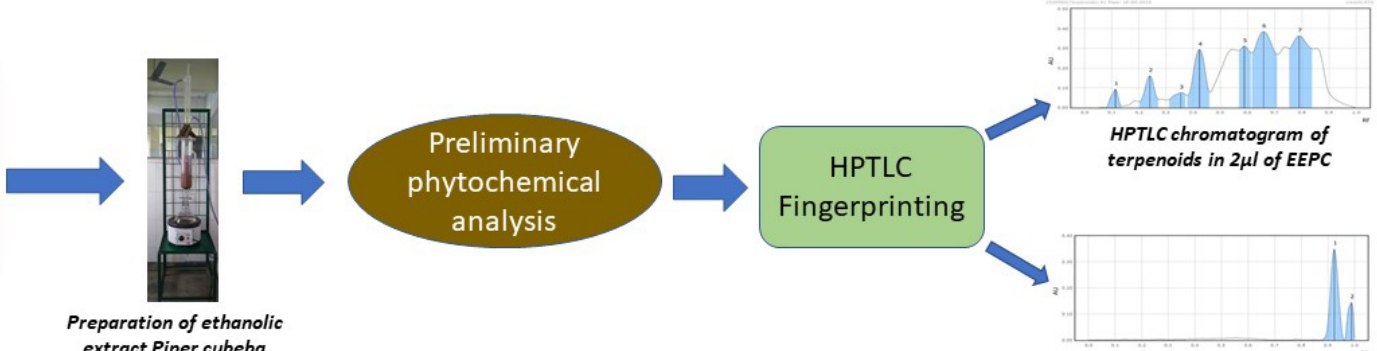
dried fruits
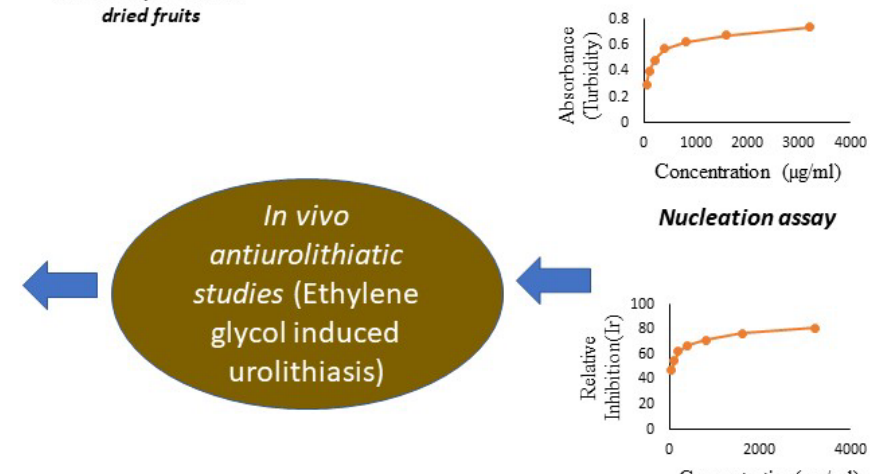

In vivo antiurolithiatic studies (Ethylene glycol induced urolithiasis)
Nucleation assay

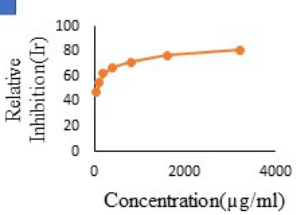

Aggregation assay
HPTLC chromatogram of flavonoids in $2 \mu$ l of EEPC
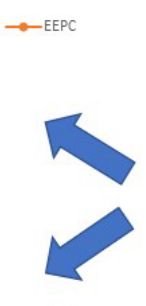

$\rightarrow$ EEPC

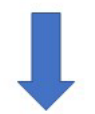

Invitro

antiurolithiatic studies 


\section{ABOUT AUTHORS}

- S. Suman: Research Scholar, Dept. of Pharmacy, Jawaharlal Nehru Technological University, Anantapur (JNTUA), Ananthapuramu, Andhra Pradesh, India. Pursuing Full-time Ph. D in JNTUA. Areas of interest- Pharmacological screening of new chemical entities for kidney diseases.

- Dr. S. V. Suresh Kumar, Professor, and HOD, Dept. of Pharmacognosy and Phytochemistry (Ratified by JNTUA), Creative Educational Society's College of Pharmacy, NH-7, Chinnatekur, Kurnool, Andhra Pradesh, India. Affiliated to JNTU Anantapur, Ananthapuramu.

Research Experience:

Screening of plants for hepatoprotective and nephroprotective activities

Standardization of Ayurvedic formulations

Cite this article: Suman S, Kumar SVS. Antiurolithiatic Activity of Ethanolic Extract of Piper cubeba Dried Fruits: An In-vitro and In-vivo Study. Pharmacogn J. 2020;12(6):1289-96. 